GJ: It seems a considerable amount of discretion has been introduced in this Bill-regulatory powers and discretionary powers that weren't there before. That concerns me because I don't understand why, and it strikes me as being potentially open to abuse.

JB: Most of it pertains tothe management of immigration. Some of it highlights the realities, things that happened administratively anyway and that are now in the regulations-for example, private sponsorship. The theory is that we can handle as many as there are sponsors, but the reality is that we can only handle as many as there are people

"I think it shows a real lack of faith in the Board members."

available in the posts abroad to process them. Clearly, the level of resources for the posts abroad are linked to the proposed level of immigration for the year. There is a de facto limit, and the regulations simply acknowledge it.

GJ: What concerns me is when a safeguard has been removed and been replaced by discretion. The answer to the concern is that the Minister can issue a permit, or we will allow the person in anyway? There's an awful lot of that kind of discretion where the safeguard has been removed and the safety net is administrative or ministerial discretion. AA: If the safe third country provisions are implemented, what is the projected number of refugees that will be affected? JB: I guess press materials say 40 percent, don't they? It's hard to predict. As the world changes, the number of refugees to Europe will rise, yet last year, the number to Canada went down. One of the goals in streamlining the process is to maintain the current level, rather than deal with growth. It depends on what countries are prescribed. The obvious one is the U.S. because more than a third of the total flow is through the U.S. Obviously, there would be ways of getting around the port of entry coming from the U.S. It's hard to predict, but for administrative purposes, we figure we can cut the number from the U.S. in half. Europe is hard to predict.

\title{
No Integrity Without An Appeal
}

\author{
Esther Ishimura, Vigil Toronto
}

I waited with great anticipation for the new amendments to the Immigration Act. I had hoped that it would make provision for a new appeal mechanism to review failed refugee claims. With great dismay and frustration, I note that there is no such provision.

I work with Vigil Toronto, a volunteer nongovernmental organization. For the last three years we have been assisting people we believe to be Convention refugees who have exhausted all legal avenues open to them, and who are scheduled for deportation from Canada. One of these people is Mr. $\mathrm{E}$.

Mr. E. is a Sri Lankan Tamil who fled Sri Lanka in 1989 after two of this friends were killed for providing equipment to the Tamil Tigers. He also unwillingly gave equipment to the Tigers and feared for his life. From 1974 until 1989 Mr. E. was detained and tortured repeatedly and brutally by the Sri Lankan army and the Indian Peacekeeping Forces. On one occasion he was also detained by the Tigers. As a result of this treatment, $\mathrm{Mr}$. E. continues to have flashbacks of his experiences of torture. He suffers from insomnia, nightmares, digestive problems and anxiety.

The Immigration and Refugee Board refused Mr. E. because they misunderstood his testimony and believed he only feared the Indian army, which had left the country. They did not recognize the cumulative effect of the numerous detentions and extreme persecution that Mr. E. endured at the hands of various armies, especially the Sri Lankan army, which is still engaged in a bitter civil war against the Tigers.

Vigil Toronto has seen over a hundred cases similar to this one in the last three years. While we acknowledge that Canada's refugee determination system is generally fair, mistakes do occur. Genuine refugees have been denied Convention refugee status because of poor legal representation, poor translation or errors made by
Immigration and Refugee Board members. As well, people come to Vigil Toronto because new evidence has arisen in their situations after the completion of their hearing. For example, a man might discover that security forces in his country have attempted to find him and, failing to do so, have killed a close relative in his place.

The refugee determination system has no adequate means to review failed claims for the purpose of correcting errors or considering new evidence. The present avenue for reviewing a failed

\section{"Canada must have a safety net to ensure that genuine refugees are not returned to the persecution from which they fled."}

decision includes an appeal to the Federal Court, a postclaim humanitarian review or an appeal to the Minister of Immigration. The appeal to Federal Court is by permission only and is granted only on errors in law, not on the facts of the case. It does not allow for new evidence to be presented.

The humanitarian and compassionate review is a perfunctory paper review that is presently done by the managers at immigration offices. To be accepted, people must show that they would be in more danger than anyone else in their country. It is no surprise that because of this stringent test, only eight out of 237 Tamils have been accepted since January 1, 1989, notwithstanding the utter horror of the civil war, arbitrary detention and human rights abuses in Sri Lanka.

The statistics for the total number of people accepted under the postclaim humanitarian and compassionate review illustrate that this process is of negligible effectiveness and dangerously unreliable. From April 1991 until April 